\title{
Pupuk Terhadap Kandungan Proksimat dan Mineral pada Suruhan Peperomia pellucida
}

\section{Organic Fertilizer Against the Content of Proximate and Mineral on Peperomia pellucida}

\author{
Yusrin Anton Puluhulawa*, Novri Youla Kandowangko, Margaretha Solang \\ Department of Biology, Universitas Negeri Gorontalo, Gorontalo, Indonesia. \\ *Corresponding author: yusrinantonpuluhulawa98@gmail.com
}

Received: January 8, 2021; Accepted: October 29, 2021; Published: October 31, 2021

\begin{abstract}
Suruhan plant is one of the plants that has properties for treatment in various diseases such as diabetes mellitus, headache, fever, and rheumatism. The plant contains antioxidants, antimicrobials and anticancers. Proximate content analysis is important to be used as data on the content of a foodstuff. One way to increase the content to be more useful is by cultivating using organic fertilizer. The purpose of this research is to find out the influence of organic fertilizers on the content of proximate, minerals on the plants. The method used was descriptive quantitative. This research was conducted in Bua Village, Batudaa District, Gorontalo Regency. Sample preparation of surname plants was carried out at the Biology Laboratory of the State University of Gorontalo for proximate and mineral analysis carried out at the Analysis Laboratory of the Bogor Pacapanen Center. The research was carried out in AugustSeptember 2020. Based on the results showed that on the content of proximate and minerals in the commission plants given organic fertilizer obtained water content of $26.60 \%$, ash content of $16.80 \%$, fat content of $2.58 \%$, protein content of $13.86 \%$, carbohydrates $40.16 \%$, iron (Fe) 18.74 ppm, calcium (Ca) 255.92 ppm.
\end{abstract}

Keywords: calsium; carbohydrates; iron; protein

Cite this as: Puluhulala, Y, A., Kandowangko, N, Y., Solang, M. \& Amalia, R. (2021). Pupuk terhadap kandungan proksimat dan mineral pada suruhan Peperomia pellucida. Agrosains : Jurnal Penelitian Agronomi, 23(2), 60-63. DOI: http://dx.doi.org/10.20961/agsjpa.v23i2.47434

\section{PENDAHULUAN}

Tanaman suruhan merupakan salah satu tanaman yang berkhasiat obat. Tanaman suruhan digunakan untuk mengobati asam urat, dan bisul. Penyakit lainnya yang dapat disembuhkan oleh tanaman suruhan antara lain mengurangi nyeri pada rematik, sakit kepala, dan penyakit kulit (Ooi et al., 2021). Tanaman suruhan secara empiris digunakan sebagai alternatif pengobatan dalam bentuk minuman herbal (Saputri et al., 2021). Tanaman suruhan mempunyai potensi untuk dijadikan sebagai minuman dengan memanfaatkan air rebusan daunnya untuk mengobati berbagai penyakit. Namun, pemanfaatan tumbuhan suruhan di Gorontalo hanya di lakukan oleh sebagian kecil masyarakat. Masyarakat Desa Sumber Melati Diski, Kabupaten Deli Serdang, Provinsi Sumatera Utara menggunakan tanaman ini untuk mengobati beberapa penyakit yaitu asam urat dan bisul karena kandungan antioksidan (Maharjan et al., 2021).

Tanaman suruhan mengandung senyawa antioksidan dan memiliki kandungan fitokimia seperti flavonoid, alkaloid, dan tanin. Berdasarkan hasil analisis bahwa suruhan mengandung proksimat $10,63 \%$, karbohidrat 46,58\%, kalsium 483, dan besi 119,3 ( $\mathrm{Ng}$ et al., 2021). Beberapa informasi tentang tumbuhan ini telah disajikan tetapi masih diperlukan penyelidikan untuk keseluruhan tanaman yang dikonsumsi dalam skala yang besar karena tanaman ini diresepkan untuk obat tradisional. Salah satu cara untuk meningkatkan kandungan proksimat dan mineral pada tanaman suruhan yakni dengan cara budidaya menggunakan pupuk organik. Penggunaan pupuk organik pada tanaman dapat mencukupi kebutuhan nutrisi serta unsur hara selama tanaman berada pada siklus pertumbuhan. Salah satu upaya dalam mengolah kesuburan tanah dan memperbaiki sifat fisik tanah, biologi tanah yaitu dengan aplikasi pupuk organik seperti kotoran ayam, eceng gondok dan serbuk gergaji (Wu et al., 2021).

Eceng gondok merupakan gulma perairan yang dapat dimanfaatkan sebagai pupuk organik cair karena memiliki kandungan bahan organik dan hara yang cukup tinggi. Eceng gondok mengandung bahan organik $78.47 \%, \mathrm{C} / \mathrm{N}$ rasio $75.8 \%, \mathrm{~N}$ total $0.28 \%, \mathrm{P}$ total 0,0011 $\%$, $\mathrm{K}$ total $0.016 \%$ dan kandungan serat $20.6 \%$ (Kusrinah et al., 2016). Pupuk eceng gondok dapat meningkatkan jumlah dan berat buah pada terong (Rahmah et al., 2021). Selain itu, kotoran ayam yang dihasilkan dari limbah hewan ternak yang dipelihara dan dibudidayakan memiliki potensi sebagai pupuk organik dan dapat memperbaiki sifat fisik kimia dan pertumbuhan tanaman. Kotoran ayam memiliki kandungan hara diantaranya $\mathrm{P} 1,82 \% \mathrm{~N} \mathrm{1,72 \% ,Mn}$ $610 \%$, Fe $3475 \%$ K 2,18\% Ca $9,23 \%$ Mg 0,86\% Zn $501 \%$ yang cukup tinggi. Unsur pembentuk serbuk gergaji terdiri dari hidrogen $(\mathrm{H})$, oksigen $(\mathrm{O})$, karbon $(\mathrm{C})$, nitrogen (N), abu serta unsur lainnya (Li et al., 2021). 
Penelitian menggunakan pupuk organik dari berbagai bahan dasar seperti eceng gondok, kotoran ayam, dan serbuk gergaji. Serbuk gergaji dapat digunakan sebagai pupuk organik. Pupuk organik serbuk gergaji memiliki pengaruh yang positif terhadap produktivitas tanaman dan tanah (Haddad et al., 2021). Berdasarkan penelitian Fatima et al., (2021) bahwa bobot biomassa segar dan kering jagung meningkat hingga 803 dan 733\%, unsur hara esensial tanah yaitu Zn 554\%, Mn 954\%, Fe 325\%, $\mathrm{Ca} 537 \%$, dan $\mathrm{Mg} 531 \%$ pada tanaman jagung dibandingkan dengan kontrol. Hal ini didukung oleh zatzat organik pada serbuk gergaji kayu seperti lignin, sellulosa, pentosa, hemisellulosa, silika, dan lain-lain (Beesigamukama et al., 2021).

Berdasarkan penelitian Sittadewi (2007) tentang aplikasi pupuk organik campuran (eceng gondok, kotoran ayam, dan serbuk gergaji) terhadap pertumbuhan tanaman suruhan (Peperomia pellucida) bahwa jumlah daun dan cabang meningkat dengan aplikasi pupuk organik campuran tersebut. Hal ini disebabkan karena pada pupuk kotoran ayam, eceng gondok dan serbuk gergaji memiliki unsur hara makro dan mikro seperti N, P, K, Mg, dan Fe yang jika dikombinasikan dapat meningkatkan pertumbuhan tanaman. Namun pengaruh berbagai jenis pupuk organik seperti eceng gondok, kotoran ayam dan serbuk gergaji terhadap kandungan proksimat dan mineral pada tanaman suruhan belum pernah dikaji. Penelitian ini bertujuan untuk mengkaji pengaruh beberapa pupuk organik terhadap kandungan proksimat dan mineral pada tanaman suruhan.

\section{BAHAN DAN METODE}

Penelitian dilakukan di Desa Bua, Kecamatan Batudaa, Kabupaten Gorontalo dengan letak astronomis I $^{\circ} 00^{\prime} 24^{\prime \prime}-1^{\circ} 02^{\prime} 00^{\prime \prime}$ Lintang Utara dan $121^{\circ}$ 59.00" - $123^{\circ} 32.00^{\prime \prime}$ Bujur Timur. Preparasi sampel tanaman suruhan dilakukan di Laboratorium Biologi Universitas Negeri Gorontalo untuk analisis proksimat dan mineral dilakukan di Laboratorium Analisis Balai Pacapanen Bogor. Penelitian dilaksanakan pada bulan Agustus-September 2020. Alat untuk preparasi sampel yaitu neraca analitik dan oven. Bahan yang diteliti yaitu bagian tanaman suruhan (batang dan daun). Jenis penelitian ini adalah deskriptif kuantitatif. Perlakuan dalam penelitian ini yaitu pupuk organik dalam bentuk padat (tanah $350 \mathrm{~g}$, eceng gondok $100 \mathrm{~g}$, kotoran ayam $350 \mathrm{~g}$, serbuk gergaji $200 \mathrm{~g}$ jadi total pupuk yang dicampur dengan tanah menjadi $1 \mathrm{~kg}$ dan dibagi pada 6 polibag. Teknik pengumpulan data yang dilakukan yakni mengukur berat basah, berat kering tanaman dan mengukur parameter lingkungan. Prosedur penelitian terdiri dari persiapan alat dan bahan untuk budidaya, pembuatan pupuk, pelaksanaan, sampai dengan preparasi tanaman. Prosedur preparasi sampel menimbang berat basah tanaman kemudian memasukkan kedalam oven pada suhu $50^{\circ} \mathrm{C}$ selama $1 \times 24$ jam. Tanaman yang telah dikeringkan dalam oven ditimbang berat keringnya setelah itu tanaman dihaluskan dan dianalisis lebih lanjut mengenai kandungan proksimat dan kalsium, serta besi.

\section{Kadar Air}

Cawan porselin dikeringkan dalam oven $105^{\circ} \mathrm{C}$ selama 3 jam, kemudian ditempatkan dalam desikator selama 1 jam. Setelah itu ditimbang dengan neraca sartorius. (a) Lalu ke dalam cawan ditambahkan sebanyak 2.0-2.5 g sampel; (b) Cawan yang berisi sampel ditempatkan dalam oven $105^{\circ} \mathrm{C}$ selama 3 jam. Setelah itu ditempatkan dalam desikator selama 1 jam. Bobot cawan dan sampel ditimbang; (c). Pengeringan dilakukan beberapa kali sampai bobot sampel yang diperoleh konstan. Analisis dilakukan 3 kali ulangan untuk masing-masing sampel.

$\%$ Bobot kering $(\mathrm{BK})=\frac{c-a}{b} \times 100 \%$

$\%$ Kadar Air = $100-\% B K$

\section{Kadar Abu}

Cawan porselin dikeringkan dalam oven $105^{\circ} \mathrm{C}$ selama 3 jam, kemudian ditempatkan dalam desikator selama 1 jam. Setelah itu cawan ditimbang dengan neraca sartorius. (a) Lalu ke dalam cawan ditambahkan sebanyak 2.0-2.5 g sampel hasil preparasi; (b) Cawan dan sampel tersebut dikeringkan dalam tanur listrik $550^{\circ} \mathrm{C}$ selama $18-24$ jam. Sampel yang telah jadi abu kemudian ditempatkan dalam desikator selama 1 jam. Bobot cawan dan abu ditimbang.

$\%$ Kadar Abu $=\frac{c-a}{b} \times 100 \%$

\section{Kadar Protein}

Sampel sebanyak 0.5-1 g ditimbang dengan menggunakan kertas, lalu dimasukan ke tabung destruksi dan ditambahkan katalis kjeltab dan $12.5 \mathrm{ml}$ $\mathrm{H}_{2} \mathrm{SO}_{4}$. Kemudian tabung destruksi diletakan pada digestor dan dilakukan proses destruksi pada suhu $415^{\circ} \mathrm{C}$ selama 1 jam. Setelah proses destruksi berlangsung tabung diangkat dan didinginkan selama 1 jam. Kemudian dilakukan proses analisis menggunakan alat kjeltec. Sebelumnya dilakukan analisis terhadap blanko dengan menempatkan tabung destruksi kosong yang akan terisi air suling secara otomatis oleh alat. Setelah itu dilakukan pengesetan tempat tabung destruksi, nomor tabung, bobot sampel, data konversi, dan konsentrasi $\mathrm{HCl}$ terstandarisasi. Data blanko digunakan untuk analisis sampel dan disimpan di dalam alat. Dari hasil analisis pada alat kjeltec akan menunjukan \%N dari sampel yang dianalisis. Analisis kadar protein dilakukan sebanyak 2 kali ulangan.

$\%$ Protein $=\% \mathrm{~N} \times 6.25$

\section{Kadar Lemak}

Sebelum dilakukan analisis kadar lemak, cangkir ekstraksi (extraction cup) dipanaskan selama 1 jam. Kemudian extraction cup ditempatkan dalam desikator selama 1 jam. Lalu ditimbang bobotnya. (a) Sebanyak kira-kira 1gram sampel dibungkus dengan kertas saring (b) dan ditempatkan dalam timbel. Timbel kemudian ditempatkan pada alat soxtec system HT. Sebanyak 40 $\mathrm{ml}$ petroleum benzena dimasukan dalam extraction cup. Setelah suhu mencapai $110^{\circ} \mathrm{C}$ extraction cup diletakan pada alat dengan posisi di bawah timbel, sehingga sampel terendam. Selama 20 menit sampel dididihkan dengan cara memutar tombol ke arah posisi boiling, lalu dilakukan pembilasan selama 30 menit dengan cara memutar tombol pada posisi rinsing. Pembilasan diulang lagi sambil menutup katup selama 40 menit dan diuapkan selama 10 menit. Extraction cup dilepaskan dari alat dan ditempatkan pada oven selama $1 / 2$ jam. Lalu extraction cup ditempatkan dalam desikator selama 1 
jam. Bobot extraction cup dan lemak yang terbentuk ditimbang.

$\%$ Kadar Lemak $=\frac{c-a}{b} \times 100 \%$

\section{Kadar Karbohidrat}

Analisis kadar karbohidrat dilakukan dengan menggunakan rumus sebagai berikut:

$\%$ Kadar Karbohidrat $=\{100 \%-($ kadar abu + kadar protein + kadar lemak)\}

\section{Analisis Mineral}

Sebuah spektrofotometer panjang gelombang, celah dan arus lampu yang digunakan untuk penentuan analisis besi adalah 248,3 m, 0,2 nm, 6,0 mA dan panjang gelombang celah dan arus lampu yang digunakan untuk analisis kalsium 422,7 nm, 1,2 nm, 4,0 $\mathrm{mA}$. Hasil untuk kandungan mineral dinyatakan sebagai mg/100 g DW (Kumar et al., 2021).

\section{HASIL DAN PEMBAHASAN \\ Berat Kering dan Berat Basah (gram/tanaman)}

Pengukuran berat basah dilakukan pada saat panen, dan pengukuran dilakukan dengan menggunakan neraca analitik dengan menimbang bagian batang dan daun tanaman suruhan. Berat kering adalah berat saat sebuah tanaman suruhan setelah di oven dan tidak mengandung kadar air di dalamnya. Pengukuran berat kering tanaman suruhan dilakukan dengan menggunakan neraca analitik. Hasil rata-rata pengukuran berat basah, berat kering batang dan daun tanaman suruhan disajikan pada Tabel 1.

Tabel 1. Rata-rata pengukuran berat kering dan berat basah batang dan daun tanaman suruhan

\begin{tabular}{cccc}
\hline $\begin{array}{c}\text { Tanaman } \\
\text { suruhan } \\
\text { (Batang dan } \\
\text { Daun) }\end{array}$ & $\begin{array}{c}\text { Berat } \\
\text { Basah } \\
(\mathrm{g})\end{array}$ & $\begin{array}{c}\text { (Berat Kering } \\
(\mathrm{g})\end{array}$ & $\begin{array}{c}\text { Serbuk } \\
(\mathrm{g})\end{array}$ \\
\hline $\begin{array}{c}\text { (A) Pupuk } \\
\text { Organik }\end{array}$ & 200 & 81 & 25 \\
\hline
\end{tabular}

\section{Hasil Analisa Proksimat dan Mineral Tanaman Suruhan}

Hasil penelitian menunjukkan bahwa kandungan proksimat pada perlakuan pupuk organik menunjukkan kadar air sebesar 26,60\% (Tabel 2). Hal ini disebabkan karena di dalam pupuk organik yang digunakan mengandung berbagai unsur hara yang baik untuk pertumbuhan tanaman sehingga dibutuhkan dalam jumlah besar pada setiap tahap pertumbuhannya, khususnya pada tahap pertumbuhan vegetatif, seperti perkembangan batang dan daun (Fang et al., 2021).

Kadar protein pada tanaman suruhan dengan aplikasi pupuk organik yaitu 13,86\%. Pupuk organik yang digunakan mempunyai nilai nitrogen yang tinggi yang terdapat pada eceng gondok dan kotoran ayam sehingga dapat memacu proses pembentukan daun tanaman. Nitrogen merupakan unsur hara pembentuk asam amino dan protein sebagai bahan dasar tanaman dalam menyusun daun (Zhong et al., 2021). Kadar lemak pada tanaman suruhan dengan aplikasi pupuk organik yaitu $2,58 \%$. Lemak dan minyak merupakan sumber energi yang paling efektif dibandingkan dengan protein dan karbohidrat, 1 gram lemak akan menghasilkan $9 \mathrm{kkal}$. Lemak dan minyak juga merupakan zat yang sangat penting untuk menjaga kesehatan tubuh manusia (Taylor et al., 2021). Kadar karbohidrat pada tanaman suruhan dengan aplikasi pupuk organik menunjukkan hasil 40,16\%. Karbohidrat selain berfungsi untuk menghasilkan energi, fungsi lain karbohidrat yaitu pemberi rasa manis pada makanan, penghemat protein, pengatur metabolisme lemak dan membantu pengeluaran feses (Chen et al., 2021). Kadar abu untuk perlakuan dengan menggunakan pupuk memperoleh hasil yaitu $16,80 \%$. Kadar abu adalah parameter untuk menunjukkan nilai kandungan bahan anorganik (mineral) yang ada di dalam suatu bahan atau produk diantaranya kalsium, kalium, fosfor, besi, magnesium, dan lain-lain (Liu et al., 2021).

Kalsium yang dihasilkan pada tanaman suruhan yang diberi pupuk organik memperoleh hasil 255,92 ppm. Keperluan terbesar kalsium terjadi pada waktu pertumbuhan, meski sudah mencapai usia dewasa kalsium masih tetap dibutuhkan pada proses pembentukan tulang (Gómez-Espinoza et al., 2021). Besi yang dihasilkan pada tanaman suruhan yang diberi pupuk organik memperoleh hasil 255,95 ppm.

Tabel 2. Hasil Kandungan Proksimat dan Mineral Tanaman Suruhan

\begin{tabular}{cl}
\hline No. & \multicolumn{1}{c}{ Parameter } \\
\hline 1. & Kadar Air $(26,60 \%)$ \\
2. & Kadar Abu $(16,80 \%)$ \\
3. & Kadar Lemak $(2,58 \%)$ \\
4. & Kadar Protein $(13,86 \%)$ \\
5. & Karbohidrat $(40,16 \%)$ \\
6. & Fe (Besi) $(18,74 \mathrm{ppm})$ \\
7. & Ca (Kalsium) $(255,92 \mathrm{ppm})$ \\
\hline
\end{tabular}

\section{KESIMPULAN}

Pupuk organik dapat meningkatkan kandungan proksimat dan mineral pada tanaman suruhan dengan memperoleh hasil dimana kadar air 26,60\%, kadar abu $16,80 \%$, kadar lemak 2,58\%, kadar protein 13,86\%, karbohidrat 40,16\% dan mineral yang terdiri dari kalsium 255,92 ppm dan besi 18,74 ppm.

\section{DAFTAR PUSTAKA}

Beesigamukama, D., Mochoge, B., Korir, N. K., K.M. Fiaboe, K., Nakimbugwe, D., Khamis, F. M., Subramanian, S., Wangu, M. M., Dubois, T., Ekesi, S., \& Tanga, C. M. (2021). Low-cost technology for recycling agro-industrial waste into nutrient-rich organikfertilizer using black soldier fly. Waste Management, 119, 183-194. https://doi.org/10.1016/j.wasman.2020.09.043

Chen, X., Zheng, J., Teng, M., Zhang, J., Qian, L., Duan, M., Wang, Z., \& Wang, C. (2021). Environmentally relevant concentrations of tralopyril affect carbohydrate metabolism and lipid metabolism of zebrafish (Danio rerio) by disrupting mitochondrial function. Ecotoxicology and Environmental Safety, 223(2), 112615. https://doi.org/10.1016/j.ecoenv.2021.112615

Fang, P., Abler, D., Lin, G., Sher, A., \& Quan, Q. (2021). Substituting OrganikFertilizer for Chemical Fertilizer: Evidence from Apple Growers in China. Land, 10(8), 858. https://doi.org/10.3390/land10080858

Fatima, I., Ahmad, M., Vithanage, M., \& lqbal, S. (2021). Abstraction of nitrates and phosphates from water by sawdust- and rice husk-derived biochars: Their 
potential as $\mathrm{N}$ - and P-loaded fertilizer for plant productivity in nutrient deficient soil. Journal of Analytical and Applied Pyrolysis, 155(November 2020), 105073.

https://doi.org/10.1016/j.jaap.2021.105073

Gómez-Espinoza, O., González-Ramírez, D., MéndezGómez, J., Guillén-Watson, R., Medaglia-Mata, A., \& Bravo, L. A. (2021). Calcium oxalate crystals in leaves of the extremophile plant colobanthus quitensis (Kunth) bartl. (caryophyllaceae). Plants, 10(9). https://doi.org/10.3390/plants10091787

Haddad, K., Jeguirim, M., Jellali, S., Thevenin, N., Ruidavets, L., \& Limousy, L. (2021). Biochar production from Cypress sawdust and olive mill wastewater: Agronomic approach. Science of the Total Environment, 752. https://doi.org/10.1016/j.scitotenv.2020.141713

Kumar, M., Puri, S., Pundir, A., Bangar, S. P., \& Changan, S. (2021). Composition of Selected Medicinal Plants for Therapeutic Uses from Cold Desert of Western Himalaya. Plants, 1429(10). https://doi.org/org/10.3390/plants10071429 Academic

Liu, R., Chen, P., Wang, Z., Rong, K., Yan, J., Liu, J., \& Deguchi, Y. (2021). Quantitative analysis of carbon content in fly ash using LIBS based on support vector regression. Advanced Powder Technology, 32(8), 2978-2987.

https://doi.org/10.1016/j.apt.2021.06.010

Maharjan, R., Thapa, R., Nagarkoti, S., \& Sapkota, P. (2021). Ethnobotanical uses of home garden species around Lalitpur district, Nepal. Asian Journal of Pharmacognosy, 4(2), 10-22.

Ng, Z. X., Than, M. J. Y., \& Yong, P. H. (2021). Peperomia pellucida (L.) Kunth herbal tea: Effect of fermentation and drying methods on the consumer acceptance, antioxidant and anti-inflammatory activities. Food Chemistry, 344(November 2020), 128738.

https://doi.org/10.1016/j.foodchem.2020.128738

Ooi, K. L., Zakaria, R., Tan, M. L., \& Sulaiman, S. F. (2021). The influence of chemical composition of potent inhibitors in the hydrolyzed extracts of antihyperuricemic plants to their xanthine oxidase activities. Journal of Ethnopharmacology, 278(April), 114294. https://doi.org/10.1016/j.jep.2021.114294

Rahmah, I. N., Sulistyono, A., \& Makhziah, M. (2021). Respon Pertumbuhan dan Hasil Tanaman Terong (Solanum melongena L.) terhadap Pemberian Paklobutrazol dan Pupuk Organik Cair Eceng Gondok. PLANTROPICA: Journal of Agricultural Science, 6(2), 154-162.

Saputri, F. C., Hutahaean, I., \& Mun'im, A. (2021). Peperomia pellucida (L.) Kunth as an angiotensinconverting enzyme inhibitor in two-kidney, one-clip Goldblatt hypertensive rats. Saudi Journal of Biological Sciences, 28(11), 6191-6197. https://doi.org/10.1016/j.sjbs.2021.06.075

Sittadewi, E. H. (2007). Pengolahan Bahan Organik Eceng Gondok Menjadi Media tumbuh untuk mendukung Pertanian Organik. Journal Teknik Lingkungan, 8(3), 229-234.
Taylor, Z. B., Stevenson, R. J., Ehrenfeld, L., \& Francis, H. M. (2021). The impact of saturated fat, added sugar and their combination on human hippocampal integrity and function: A systematic review and metaanalysis. Neuroscience and Biobehavioral Reviews, 130(April), 91-106. https://doi.org/10.1016/j.neubiorev.2021.08.008

Wu, J., Sha, C., Wang, M., Ye, C., Li, P., \& Huang, S. (2021). Effect of organikfertilizer on soil bacteria in maize fields. Land, 10(3), 1-14. https://doi.org/10.3390/land10030328

Zhong, C., Jian, S. F., Chen, D. L., Huang, X. J., \& Miao, J. H. (2021). Organiknitrogen sources promote andrographolide biosynthesis by reducing nitrogen metabolism and increasing carbon accumulation in Andrographis paniculata. Plant Physiology and Biochemistry, 164, 82-91. https://doi.org/10.1016/j.plaphy.2021.04.016 